\title{
Effects of dust deposition on iron cycle in the surface Mediterranean Sea: results from a mesocosm seeding experiment
}

\author{
T. Wagener ${ }^{1,2, *}$, C. Guieu ${ }^{1,2}$, and N. Leblond ${ }^{1,2}$ \\ ${ }^{1}$ CNRS-INSU, Laboratoire d'Océanographie de Villefranche/Mer, UMR 7093, Observatoire Océanologique, \\ Villefranche-sur-Mer, France \\ ${ }^{2}$ Université Pierre et Marie Curie - Paris 6, LOV, UMR 7093, Observatoire Océanologique, Villefranche-sur-Mer, France \\ *now at: Laboratoire d'Océanographie Physique et Biogéochimique, UMR 6535, CNRS, Université de la Méditerranée, \\ Marseille, France
}

Received: 31 March 2010 - Published in Biogeosciences Discuss.: 16 April 2010

Revised: 4 November 2010 - Accepted: 11 November 2010 - Published: 23 November 2010

\begin{abstract}
Soil dust deposition is recognized as a major source of iron to the open ocean at global and regional scales. However, the processes that control the speciation and cycle of iron in the surface ocean after dust deposition are poorly documented mainly due to the logistical difficulties to investigate in-situ, natural dust events. The development of clean mesocosms in the frame of the DUNE project (a DUst experiment in a low Nutrient low chlorophyll Ecosystem) was a unique opportunity to investigate these processes at the unexplored scale of one dust deposition event. During the DUNE-1-P mesocosm seeding experiment, iron stocks (dissolved and particulate concentrations in the water column) and fluxes (export of particulate iron in sediment traps) were followed during 8 days after an artificial dust seeding mimicking a wet deposition of $10 \mathrm{~g} \mathrm{~m}^{-2}$. The addition of dust at the surface of the mesocosms was immediately followed by a decrease of dissolved iron $[\mathrm{dFe}]$ concentration in the $0-10 \mathrm{~m}$ water column. This decrease was likely due to $\mathrm{dFe}$ scavenging on settling dust particles and mineral organic aggregates. The scavenging ratio of dissolved iron on dust particles averaged $0.37 \pm 0.12 \mathrm{nmol} \mathrm{mg}^{-1}$. Batch dissolution experiments conducted in parallel to the mesocosm experiment showed a increase (up to $600 \%$ ) in dust iron dissolution capacity in dust-fertilized waters compared to control conditions. This study gives evidences of complex and unexpected effects of dust deposition on surface ocean biogeochemistry: (1) large dust deposition events may be a sink for surface ocean dissolved iron and (2) successive dust deposition events may induce different biogeochemical responses in the surface ocean.
\end{abstract}

Correspondence to: $\mathrm{T}$. Wagener (thibaut.wagener@univmed.fr)

\section{Introduction}

Deposition of atmospheric particles at the ocean-atmosphere interface constitutes a flux of chemical elements to the surface ocean. When excluding sea-salt particles, most of the mass flux of atmospheric particles is made of fine mineral particles from lithogenic origin (Andreae, 1996). These particles are emitted from arid or semi-arid areas and transported over long distances through atmospheric circulation. The elemental composition of the mineral particles that deposit at the surface ocean is determined by the elemental composition of the continental source area (Claquin et al., 1999; Guieu et al., 2002a) and the chemical processes that affect the particles during transport (Desboeufs et al., 2003; Shi et al., 2009). As the erodible continental crust contains significant amounts of biogeochemically significant elements (Wedepohl, 1995), dust deposition is recognized as a significant source of micro- and macro- nutrients to the surface ocean (Jickells et al., 2005; Mahowald et al., 2008; Duce et al., 2009).

As often highlighted by impressive satellite pictures (NASA EO, 2010), large dust deposition events are episodic phenomena. This important temporal variability in dust deposition hinders the assessment of the time scales needed to understand the response of the surface ocean (Aumont et al., 2008; Volpe et al., 2009). The occurrence of a large dust deposition event can be conceptually investigated as a chemical perturbation to the oceanic system and the episodic nature of the phenomena may certainly lead to non linear biogeochemical responses. Iron cycling has received a considerable impetus during the last two decades, due to its role in controlling marine productivity in HNLC areas (Boyd et al., 2007) and to its (co)-limiting role on $\mathrm{N}_{2}$ fixation in oligotrophic

Published by Copernicus Publications on behalf of the European Geosciences Union. 
areas (Mills et al., 2004). However, due to the logistical difficulties to investigate the response to a dust pulse at the scale of an event, in situ studies of the processes occurring at these small time scales are quasi undocumented. Moreover, a large scientific debate has taken place on the role of atmospheric dust iron deposition to the surface ocean on the climate variability at millennium time scales (Martin et al., 1990; Watson et al., 2000; Bopp et al., 2003). However, the underlying physico-chemical processes that govern iron cycling at the ocean-atmosphere interface are still poorly understood (Baker and Croot, 2010). On one hand, laboratory experiments emphasize the release of iron when dust is in contact with seawater mainly controlled by dissolution processes (Baker and Croot, 2010). On the other hand, several studies present evidence of inverse processes limiting the dissolved iron concentrations, as re-precipitation (notably for high dust concentrations) (Spokes and Jickels, 1995; Bonnet et Guieu, 2004) or iron adsorption on particles (Zhuang and Duce, 1993).

The project DUNE (a DUst experiment in a low Nutrient low chlorophyll Ecosystem) aims at better understanding the effect of dust deposition on the biogeochemistry of surface waters of the Mediterranean Sea (Guieu et al., 2010b). The approach applied in this project was to perform dust addition experiments onto large clean mesocosms. The original design of these mesocosms represented a unique opportunity to study the iron cycle at a scale which has been poorly explored so far. The main objective of this study is to quantify dissolution and adsorption processes of dissolved iron that occurs from (or at) mineral particles surface. These processes modulate the net effect of the input of atmospheric particles as a source or a sink of bioavailable iron to the surface ocean ecosystem.

\section{Material and Methods}

\subsection{Experiment design}

The mesocosm experiment design and the accuracy of the strategy developed in the frame of the DUNE project is described in detail in Guieu et al. (2010b). In summary, the deployed mesocosms were cylindrical with a diameter of $2.3 \mathrm{~m}$ and a depth of $12 \mathrm{~m}$. The bottom of the mesocosms was conic and a sediment trap collecting the exported material was adapted at the apex (at a depth of $14.2 \mathrm{~m}$ ). The total volume of water in each mesocosm was $52 \mathrm{~m}^{3}$. A system of permanent PVC tubing allowed to sample at three different depths $(-0.1,-5$ and $-10 \mathrm{~m})$ by connecting a Teflon pump. Mesocosms were covered in order to avoid possible additional inputs from natural dust events. The covers were designed in order to let the maximum light reach the water body inside the mesocosm and to allow gas exchanges.
In June 2008, six mesocosms entirely designed in plastic were deployed in the bay of Elbo (Scandola Marine preservation area $-8.554^{\circ} \mathrm{E}, 42.374^{\circ} \mathrm{N}$ ), a site characterized by oligotrophic conditions in summer. The DUNE-1-P fertilization experiment was conducted with the following protocol: after deployment and closing of the mesocosms, sampling was performed to determine the initial conditions. Three mesocosms (D1, D2 and D3, hereafter referred as "DUST-Meso") were amended with $41.5 \mathrm{~g}$ of dust each with a trace metal clean spray. This corresponded to a deposition of $10 \mathrm{~g} \mathrm{~m}^{-2}$ and would correspond to a theoretical particle concentration of $0.798 \mathrm{mg} \mathrm{L}^{-1}$ assuming an homogeneous distribution of the particles over the entire mesocosm. The amendment was made with a processed dust (Al: $4.12 \pm 0.39 \%$ mass. and $\mathrm{Fe}$ : $2.31 \pm 0.04 \%$ mass.) diluted in 2 liters of ultrapure water in order to mimic a wet deposition event (see Guieu et al., $2010 \mathrm{~b}$ for details). Dust was obtained through a mechanical treatment of soils from a dust source areas in southern Tunisia to obtain fine particles and further physico-chemical treatment in the laboratory in order to mimic the $\mathrm{pH}$ gradients and the incorporation of organic material normally observed during cloud processing of dust (see Guieu et al., 2010b for details). Three other mesocosms (C1, C2 and C3, hereafter referred as "CONTROL-Meso") were kept unamended. The time of the dust addition corresponds to the theoretical start of the experiment $(t 0)$. Sampling for most of the parameters was performed at a daily scale during 8 days. Every 48 hours one cast (at $0.1,5$ and $10 \mathrm{~m}$ ) was additionally made outside the mesocosms and the sediment traps were recovered and replaced.

All material used for this study was cleaned following trace-metal clean procedures (Bruland et al., 1979) and for analytical work, all manipulations took place under a class 100 laminar flow bench.

\subsection{Dissolved iron concentration analysis}

Samples for dissolved iron concentration [dFe] were filtered during sampling through a $0.2 \mu \mathrm{m}$ cartridge filter (Sartobran, Sartorius, Germany) adapted on the pumping system and collected in $60 \mathrm{~mL}$ polyethylene bottles. Samples were acidified to $\mathrm{pH}<2$ with $\mathrm{HCl}$ (Merck, Ultrapur, Germany) directly after collection and were analyzed after at least $24 \mathrm{~h}$. [dFe] was analyzed by flow injection with online preconcentration and chemiluminescence detection following exactly the same protocol, instrument and analytical parameters as described in Bonnet and Guieu (2006). Detection limit (DL) was $10 \mathrm{pM}$ and blanks were around $50 \mathrm{pM}$. An internal acidified seawater standard was measured every day in order to control the stability of the analysis. The reliability of the method was controlled by analyzing the D2 SAFE seawater standard (Johnson et al., 2007). 


\subsection{Particulate iron [pFe] and aluminium [pAl] concentration analysis in the water column}

In order to follow the settling of the added mineral particles through the mesocosms, particulate iron [pFe] and aluminium $[\mathrm{pAl}]$ were measured during the experiment. An "easy to run" protocol was preferred over common protocols designed to reach low detection limits and requiring larger volumes of filtered water. Samples were collected on $47 \mathrm{~mm}$ (pore size: $0.2 \mu \mathrm{m}$ ) cellulose acetate filters (Sartorius) previously washed with diluted $\mathrm{HCl}$ and rinsed thoroughly with ultrapure water. Filters were placed in polypropylene filter holders connected to the Teflon pump directly from the mesocosms. For each sample one liter of seawater was filtered. After collection, filters were dried under a laminar flow bench and kept at room temperature until analysis. One half of the collected filters were $\mathrm{HNO}_{3} / \mathrm{HF}$ acid-digested using Suprapur reagents at $150^{\circ} \mathrm{C}$ in PTFE vials. After complete evaporation, samples where diluted in $0.1 \mathrm{M} \mathrm{HNO}_{3}$ and analyzed for iron and aluminium concentrations by ICP-AES (Jobin Yvon - JY 138"Ultrace"). A certified marine sediment reference material (GBW from NRCCRM china) was digested following the same protocols to test the reliability of the method (Recovery for $\mathrm{Al}=94-96 \%$, for $\mathrm{Fe}=99$ $101 \%$ ). Reagent blanks and filter blanks were included as control for possible contamination during the analytical process. Blank values were under the detection limit (3.5 ppb for $\mathrm{Fe}$ and $8 \mathrm{ppb}$ for $\mathrm{Al}$ corresponding to a detection limit for $[\mathrm{pFe}]=0.10 \mu \mathrm{g} \mathrm{L}^{-1}$ and $[\mathrm{pAl}]=0.24 \mu \mathrm{g} \mathrm{L}^{-1}$ in the seawater with the protocol used).

\subsection{Aluminium (pAl) and iron (pFe) measurements in the sediment trap}

The samples collected in the sediment trap were treated following the standard protocol developed at the national service "Cellule Piege" of the French INSU-CNRS. Details for this protocol can be found in Guieu et al. (2005). Aluminium and iron were measured on dried aliquots of the collected material with the same instrument and the same protocol than described above for particulate iron $[\mathrm{pFe}]$ and aluminium [pAl] measurements in seawater.

\subsection{Dust dissolution experiments during the DUNE-1-P experiment}

At four selected times during the DUNE-1-P experiment, batch dust dissolution experiments were performed on filtered $(<0.2 \mu \mathrm{m})$ seawater collected in the mesocosms at $5 \mathrm{~m}$. The aim of this additional "bottle" experiment was to investigate the effect of dust fertilization on the dissolution of additional dust inputs. The protocol used for this dissolution experiments is described in Wagener et al. (2008). Briefly, the same type of dust used for seeding the mesocosms was first diluted in $10 \mathrm{~mL}$ of Milli-Q water. $1 \mathrm{~mL}$ of this mother solution was immediately added to $200 \mathrm{~mL}$ of filtered seawater to a final concentration of $5 \mathrm{mg} \mathrm{L}^{-1}$. Dissolved iron concentration $[\mathrm{dFe}]$ was determined after $72 \mathrm{~h}$. As discussed in Wagener et al. (2008), this simple protocol, even if subject to adsorption issues on batch reactor walls, is valuable to assess solubility variations.

\section{Results}

All data collected in this study were added to a database which is available as online supplementary information. All samples were labeled with an incremented cast number, the mesocosm name and the depth of collection. For all samples, time is " $t \mathrm{x}$ ", where $\mathrm{x}$ are hours since the $t 0$ reference fertilization time.

\subsection{Evolution of iron stocks in the mesocosms}

The evolution of $[\mathrm{dFe}]$ in the mesocosms is reported on Fig. 1. The initial $[\mathrm{dFe}]$ averaged $2.5 \mathrm{nM}$ between surface and $10 \mathrm{~m}$. The main trend observed during the eight days of the experiment is consistent among the triplicate mesocosms. In the dust-amended mesocosms ("DUST-Meso": D1, D2 and $\mathrm{D} 3),[\mathrm{dFe}]$ decreased by $0.7 \mathrm{nM} 6 \mathrm{~h}$ after dust addition whereas in the control mesocosms ("CONTROL-Meso": C1, $\mathrm{C} 2$ and $\mathrm{C} 3)[\mathrm{dFe}]$ remained constant at $2.5 \mathrm{nM}$ during the experiment with an increase (reaching $3.2 \mathrm{nM}$ for one mesocosm) at $10 \mathrm{~m}$ at the end of the experiment. Values from outside the mesocosms are reported in the supplementary information as "OUT" and showed no significant differences with values in "CONTROL-Meso". A statistical evaluation of the reproducibility of triplicates mesocosms and the coherence between CONTROL-Meso and OUT can be found in Guieu et al. (2010b).

The evolution of $[\mathrm{pFe}]$ in DUST-Meso is reported on Fig. 2. [pFe] was below $1 \mu \mathrm{g} \mathrm{L}^{-1}$ before the dust addition. Six hours after the dust addition, $[\mathrm{pFe}]$ increased to values up to $36 \mu \mathrm{g} \mathrm{L}^{-1}$ at the surface of the mesocosms. This increase was still detectable after $24 \mathrm{~h}$ at 5 and $10 \mathrm{~m}$. A fast decrease in the following three days was observed at all depths. From day four, $[\mathrm{pFe}]$ in DUST-Meso remained constant with values slightly higher to those before dust addition. The evolution of [pFe] in CONTROL-Meso was only measured at $5 \mathrm{~m}$ and is reported in the database (supplementary information). Values were low $\left(<1 \mu \mathrm{g} \mathrm{L}^{-1}\right.$ or below the detection limit) and constant for the entire duration of the experiment. Variability among the replicates was higher in $[\mathrm{pFe}]$ than in [dFe]. The low volume of filtered water (1 liter) is likely too low to integrate the small scale variability in the particulate distribution within a mesocosm. 

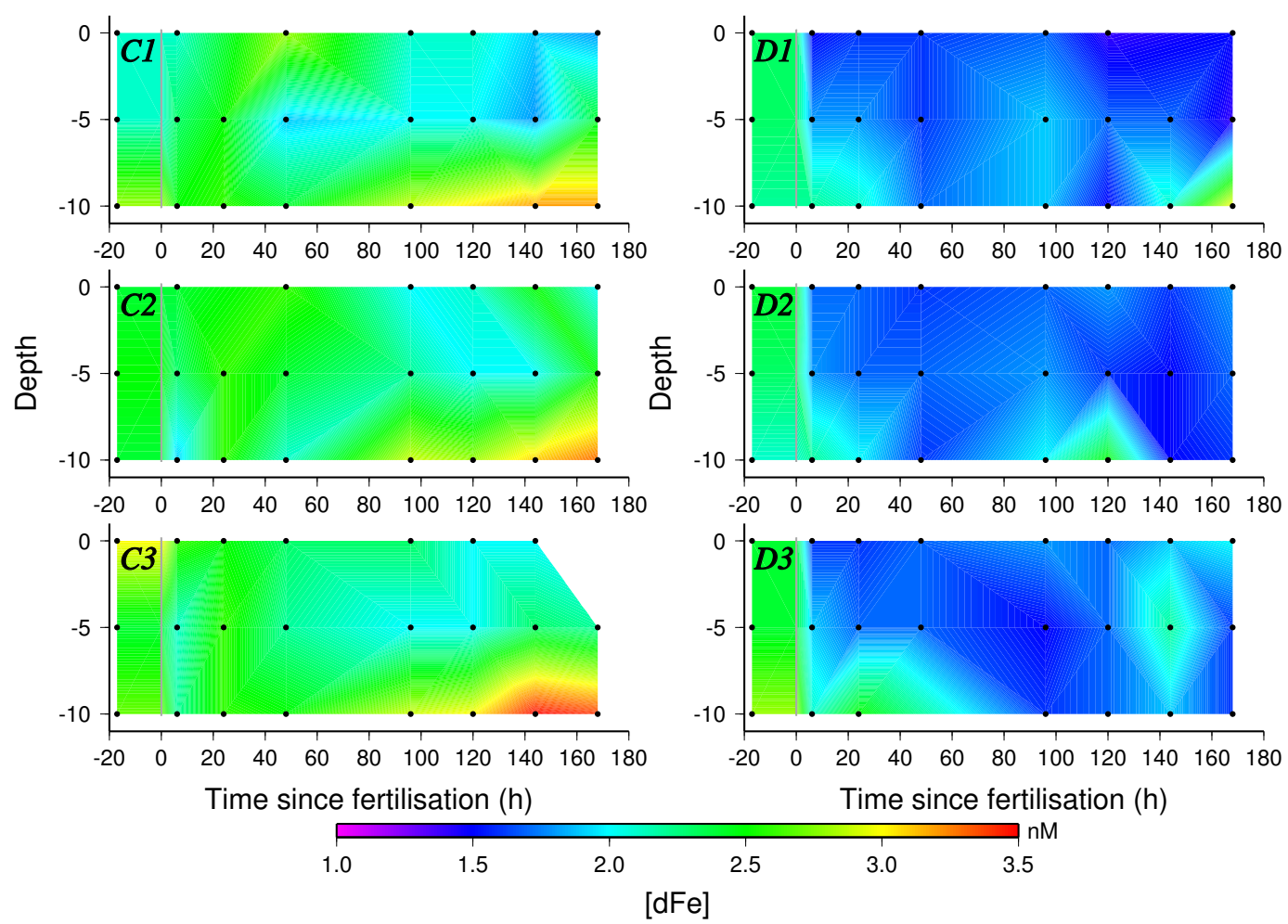

Fig. 1. Evolution of dFe concentrations ([dFe] in $\mathrm{nM})$ during the DUNE-1-P experiment in all mesocosms.
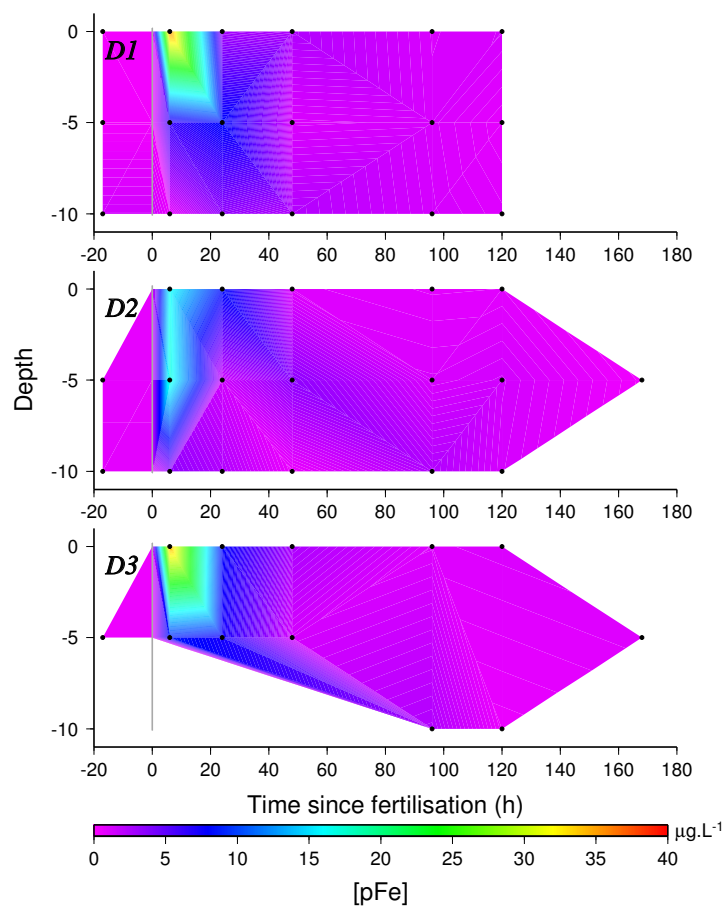

Fig. 2. Evolution of $\mathrm{pFe}$ concentrations ([pFe] in $\mu \mathrm{g} \mathrm{L}-1)$ during the DUNE-1-P experiment in mesocosms D1, D2 and D3.

\subsection{Particulate iron in the sediment traps}

Data on particulate iron that was exported down to the sediment trap of the mesocosms are reported on Table 1. The mass of particulate iron $(\mathrm{pFe})$ per sample and the cumulative mass of $\mathrm{pFe}$ for the entire experiment are reported. In the CONTROL-Meso, mass of pFe exported ranged from 0.7 to $8.5 \mathrm{mg}$ with cumulative masses at the end of experiment ranging from 8.3 to $11.5 \mathrm{mg}$. For DUST-Meso, the mass of $\mathrm{pFe}$ collected into a single sample was as high as $340 \mathrm{mg}$ with cumulative masses over the entire experiment ranging from 434 to $538 \mathrm{mg}$.

Daily $\mathrm{pFe}$ fluxes calculated from $(\mathrm{pFe})$ from each trap ranged between 0.08 and $1.02 \mathrm{mg} \mathrm{m}^{-2} \mathrm{day}^{-1}$ for CONTROL-Meso and between 1.46 and $40.4 \mathrm{mg} \mathrm{m}^{-2}$ day $^{-1}$ for DUST-Meso. The highest fluxes for DUST-Meso were recorded during the first $72 \mathrm{~h}$ of the experiment. After $120 \mathrm{~h}$, the fluxes in DUST-Meso decreased by one order of magnitude but were still higher than in the CONTROLMeso. When integrated over the entire duration of the experiment, $\mathrm{pFe}$ fluxes were ca. 50 times higher in DUST-Meso $\left(15-18.7 \mathrm{mg} \mathrm{m}^{-2} \mathrm{day}^{-1}\right)$ than in CONTROL-Meso (0.29$0.55 \mathrm{mg} \mathrm{m}^{-2}$ day $^{-1}$ ). 
Table 1. Fe masses and fluxes exported to the sediment traps during the DUNE-1-P experiment.

\begin{tabular}{|c|c|c|c|c|c|c|}
\hline $\begin{array}{l}\text { Mesocos } \\
\mathrm{m}\end{array}$ & $\begin{array}{l}\text { Time }^{1} \\
\text { (hours) }\end{array}$ & $\begin{array}{l}\text { Collection } \\
\text { time }^{2} \\
\text { (hours) }\end{array}$ & $\begin{array}{l}\text { Mass } \mathrm{Fe}^{3} \\
(\mathrm{mg})\end{array}$ & $\begin{array}{l}\text { Mass Fe } \\
\text { cum. }{ }^{4} \\
\text { (mg) }\end{array}$ & $\begin{array}{l}\text { Flux Fe } \mathrm{Fe}^{5} \\
\left(\mathrm{mg} \mathrm{m}^{-2} \mathrm{~d}^{-1}\right)\end{array}$ & $\begin{array}{l}\text { Flux Fe } \\
\text { cum. }^{6} \\
\left(\mathrm{mg} \mathrm{m}^{-2} \mathrm{~d}^{-1}\right)\end{array}$ \\
\hline \multirow[t]{4}{*}{$\mathrm{C} 1$} & 24 & 24 & 3.3 & 3.3 & 0.8 & 0.8 \\
\hline & 72 & 48 & 2.3 & 5.6 & 0.28 & 0.45 \\
\hline & 120 & 48 & 0.7 & 6.3 & 0.08 & 0.3 \\
\hline & 168 & 48 & 2 & 8.3 & 0.24 & 0.29 \\
\hline \multirow[t]{4}{*}{$\mathrm{C} 2$} & 24 & 24 & 0.8 & 0.8 & 0.19 & 0.19 \\
\hline & 72 & 48 & 3.6 & 4.4 & 0.43 & 0.35 \\
\hline & 120 & 48 & 4.5 & 8.9 & 0.54 & 0.43 \\
\hline & 168 & 48 & 1 & 9.9 & 0.12 & 0.34 \\
\hline \multirow[t]{4}{*}{ C3 } & 24 & 24 & 2.2 & 2.2 & 0.53 & 0.53 \\
\hline & 72 & 48 & 8.5 & 10.7 & 1.02 & 0.86 \\
\hline & 120 & 48 & 0.8 & 11.5 & 0.1 & 0.55 \\
\hline & 168 & 48 & NA & NA & NA & NA \\
\hline \multirow[t]{4}{*}{ D1 } & 24 & 24 & 122.9 & 122.9 & 29.6 & 29.6 \\
\hline & 72 & 48 & 340.3 & 463.2 & 41 & 37.2 \\
\hline & 120 & 48 & 54.4 & 517.6 & 6.55 & 24.9 \\
\hline & 168 & 48 & 20.4 & 538.0 & 2.46 & 18.5 \\
\hline \multirow[t]{4}{*}{ D2 } & 24 & 24 & 87.5 & 87.5 & 21.08 & 21.1 \\
\hline & 72 & 48 & 235.2 & 322.7 & 28.33 & 25.9 \\
\hline & 120 & 48 & 144.7 & 467.4 & 17.43 & 22.5 \\
\hline & 168 & 48 & 23 & 490.4 & 2.77 & 16.9 \\
\hline \multirow[t]{4}{*}{ D3 } & 24 & 24 & 167.6 & 167.6 & 40.38 & 40.4 \\
\hline & 72 & 48 & 168.3 & 335.9 & 20.27 & 27 \\
\hline & 120 & 48 & 86.8 & 422.7 & 10.46 & 20.4 \\
\hline & 168 & 48 & 12.1 & 434.8 & 1.46 & 15 \\
\hline
\end{tabular}

${ }^{1}$ Time of recovery of the sediment trap in hours since the fertilization.

2 Time of deployment and collection of the sediment trap in hours.

${ }^{3}$ Mass of iron recovered in the trap at time $t$ in $\mathrm{mg}$.

${ }^{4}$ Cumulated mass of iron recovered in the trap since the begin of the experiment in mg.

${ }^{5}$ Flux of iron recovered at time $t$. Estimated as the mass of iron divided trough the time of collection and the surface of the mesocosm $\left(4.15 \mathrm{~m}^{2}\right)$ in $\mathrm{mg} \mathrm{m}^{-2} \mathrm{~d}^{-1}$.

${ }^{6}$ Cumulated of iron recovered since the begin of the experiment Estimated as the cumulated mass of iron divided through the time $t$ and the surface of the mesocosm in mg m ${ }^{-2} \mathrm{~d}^{-1}$.

\subsection{Aluminium and iron in the particulate matter}

Particulate aluminium concentration $[\mathrm{pAl}]$ in the water column and the sediment traps were measured jointly with iron (data available in the database - Supplementary information). The relationship between $[\mathrm{pAl}]$ and $[\mathrm{pFe}]$ in the water column and in the sediment traps are reported in Fig. 3. [pAl] and $[\mathrm{pFe}]$ were significantly correlated both in the water column (slope of 0.44 , intercept close to $0, n=68, p<0.001$ ) and in the sediment traps(slope of 0.58 , intercept close to 0 , $n=23, p<0.001$ ). The slopes of both correlations are significantly different. However if the four samples with [pAl] concentrations higher than $30 \mu \mathrm{g} \mathrm{L}-1$ are discarded in the water column dataset, the slope ( $\mathrm{Fe} / \mathrm{Al}$ ratio) is 0.53 and hardly differs from the ratio in the sediment trap. These four samples correspond to the higher particulate concentrations encountered directly after the dust addition. The formation of dust aggregates with organic matter at this time could have slightly changed the Fe/Al ratio of the collected particulate matter. The $\mathrm{Fe} / \mathrm{Al}$ ratio of the dust introduced for the fertilization is $0.56 \pm 0.06$ (Guieu et al., 2010b).

\subsection{Dissolution of dust iron in batch experiments}

Results of the batch dissolution experiments are presented on Fig. 4. Dissolution at selected times after the dust addition is expressed as $\Delta[\mathrm{dFe}]_{72 \mathrm{~h}}$ (Eq. 1).

$\Delta[\mathrm{dFe}]_{72 \mathrm{~h}}=[\mathrm{dFe}]_{72 \mathrm{~h}}-[\mathrm{dFe}]_{0}$

where $[\mathrm{dFe}]_{72 \mathrm{~h}}$ is the $\mathrm{dFe}$ concentration after $72 \mathrm{~h}$ of contact time between the filtered seawater and dust particles in the batch reactor. $\left[\mathrm{dFe}_{0}\right.$ is the concentration in the filtered seawater before addition of dust particles to the batch reactor and corresponds to $[\mathrm{dFe}]$ measured in the mesocosms at the sampling time of the filtered seawater. A good reproducibility was obtained among the replicate mesocosms with coefficient variations ranging from 9 to $22 \%$ for $\Delta[\mathrm{dFe}]_{72 \mathrm{~h}}>0.1 \mathrm{nM}$. 


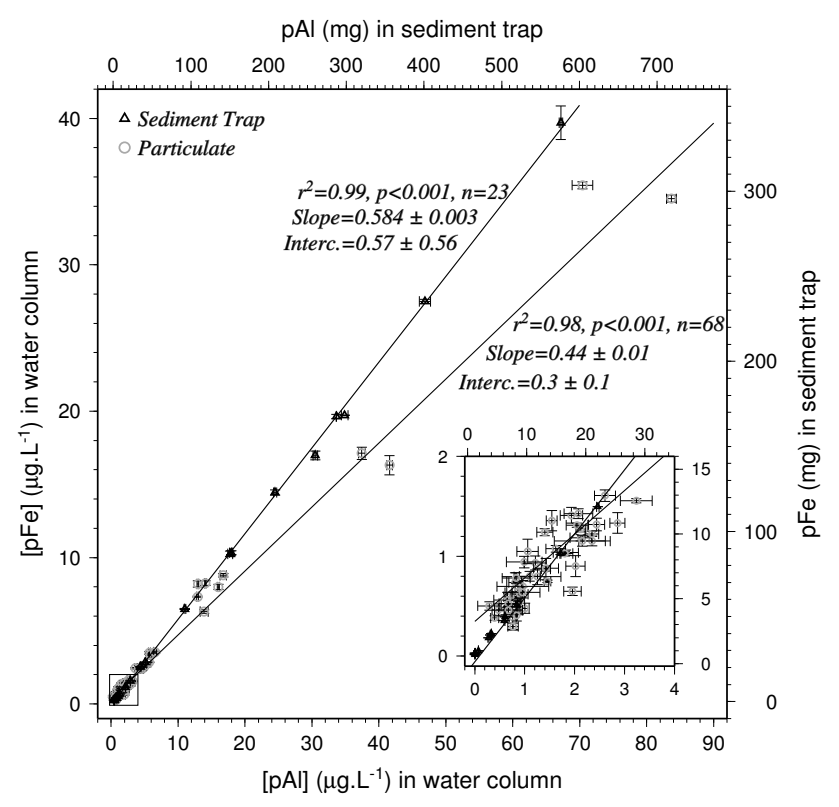

Fig. 3. $[\mathrm{pFe}]$ versus $[\mathrm{pAl}]$ in sediment trap and in the water colum. Black triangles (Right and top axes) are for sediment trap data, in mg. Open circles (Left and bottom axes) are for particulate in the water column, in $\mu \mathrm{g} \mathrm{L}^{-1}$. Both sets of axis are proportional.

$\Delta[\mathrm{dFe}]_{72 \mathrm{~h}}$ remained close to 0 when using water from CONTROL-Meso whereas it reached values between 0.5 and $1 \mathrm{nM}$ when using water from DUST-Meso for the first $120 \mathrm{~h}$ after the dust seeding in the mesocosm. Dissolution $\left(\Delta[\mathrm{dFe}]_{72 \mathrm{~h}}\right)$ increased slightly in water collected from CONTROL-Meso $(0.5 \mathrm{nM}) 168 \mathrm{~h}$ after the dust seeding in the mesocosm and it increased to $3 \mathrm{nM}$ with water collected in DUST-meso at the same time step (t168).

\section{Discussion}

\subsection{Initial iron concentration and iron budget during the DUNE-1-P experiment}

Dissolved iron concentration $[\mathrm{dFe}]$ measured outside the mesocosms and inside before the dust addition $(2.5 \mathrm{nM})$ are in the highest range of former measurements at the open sea DYFAMED time series station $\left(43^{\circ} 25^{\prime} \mathrm{N}, 07^{\circ} 52^{\prime} \mathrm{E}\right)$ in the western Mediterranean Sea (Bonnet and Guieu, 2006; Sarthou and Jeandel, 2001; Guieu et al., 2002b). Two reasons can explain these higher $[\mathrm{dFe}]$ values:

1. A Saharan dust deposition event associated with dry deposition occurred in the NW Mediterranean Sea two weeks before the beginning of the experiment ( 26 to 28 May 2008). Associated with this event, a dust flux of $382 \mathrm{mg} \mathrm{m}^{-2}$ was recorded at Galeria (Corsica, France), close to the mesocosm deployment site (K. Desboeufs, personal communication, 2010). This

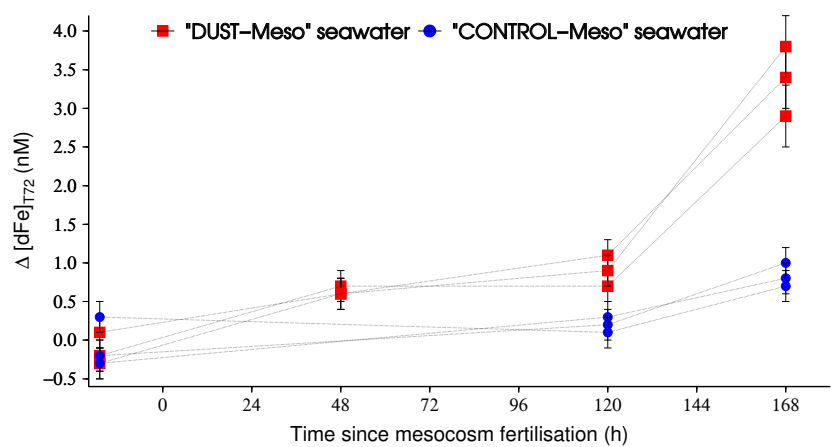

Fig. 4. Results from dust dissolution in batch experiments with filtered seawater collected in the mesocosms. The $\mathrm{X}$ axis corresponds to the time of collection of the filtered seawater in the mesocosms and addition of dust to the batch reactor (Teflon bottles). It indicates the time spent since the mesocosm fertilization. The $\mathrm{Y}$ axis corresponds to the dissolution measured after $72 \mathrm{~h}$ of contact time between dust particles and seawater in the batch reactors. Dissolution is expressed as the difference between $[\mathrm{dFe}]$ in seawater after $72 \mathrm{~h}$ of contact time and $[\mathrm{dFe}]$ at the time of the water collection in the corresponding mesocosm $\left(\Delta[\mathrm{dFe}]_{72} \mathrm{~h}\right.$ in $\left.\mathrm{nM}\right)$.

dust deposition event could have increased [dFe] in surface stratified waters as has been described by Bonnet and Guieu (2006) and Sedwick et al. (2005).

2. Rain events occurred twenty to ten days before the start of the experiment (K. Desboeufs, personal communication, 2010) and iron could have been delivered to the study area through surface runoff from surrounding lands. This last point would indicate that even if the study site has biogeochemical features typical of open ocean, it may punctually be subject to coastal influences.

Particulate iron [pFe] before the dust addition or in CONTROL-Meso were in the range of values reported for the surface waters of the NW Mediterranean Sea (Sarthou and Jeandel, 2001) and was likely dominated by lithogenic material. Indeed, even if the cellular content of iron in marine microorganisms is highly variable (e.g. Veldhuis et al., 2005), based on a biogenic $\mathrm{Fe} / \mathrm{C}$ ratio of $400 \mu \mathrm{mol} / \mathrm{mol}-\mathrm{C}$ (highest range of observations (Brand, 1991)), the biogenic Fe derived from particulate organic carbon (data not shown) in the mesocosms would represent 1 to $10 \%$ of the measured [pFe] before addition of dust. The clear dominance of iron from lithogenic origin is confirmed by the crustal signal (0.53) of the $[\mathrm{pFe}] /[\mathrm{pAl}]$ ratio.

All iron reservoirs were measured during the whole duration of the experiment in mesocosms D1 and D2 allowing to construct an iron budget in those two mesocosms (Table 2). The possibility to construct a mass budget based on iron during the experiment may be relevant in order to assess uncertainties in fluxes estimation during the experiment. At each 
Table 2. Iron budget in the mesocosms at different time $t$ in $\mathrm{mg}$.

\begin{tabular}{lrrrrrrrr}
\hline Time & 0 & 24 & 120 & 168 & 0 & 24 & 120 & 168 \\
\hline Mesocosm & \multicolumn{7}{c}{ D1 } & \multicolumn{7}{c}{ D2 } \\
\hline Input $^{1}$ & 959 & 0 & 0 & 0 & 959 & 0 & 0 & 0 \\
DFe Stock $^{2}$ & 7 & 6 & 5 & 6 & 7 & 6 & 6 & 5 \\
PFe Stock $^{3}$ & 41 & 270 & 52 & 54 & 42 & 169 & 67 & 43 \\
Export $^{4}$ & 0 & 123 & 518 & 538 & 0 & 88 & 467 & 490 \\
Sum & 1007 & 399 & 575 & 598 & 1008 & 263 & 540 & 538 \\
\% recorery & 100 & 40 & 57 & 59 & 100 & 26 & 54 & 53 \\
\hline
\end{tabular}

${ }^{1}$ Mass of iron introduced during the fertilization.

2 Mass of iron in the water column in the form of dissolved iron $(<0.2 \mu \mathrm{m})$. Between 0 and $10 \mathrm{~m}$, the stock is estimated through integration of the concentration between the three sampling depth. From $10 \mathrm{~m}$ to the bottom of the mesocosms a constant concentration equal to the concentration is assumed and the stock is estimated with taking into account the conic bottoms of the mesocosms.

${ }^{3}$ Mass of iron in the water column in the form of particulate iron $(>0.2 \mu \mathrm{m})$. Determined as described at point ${ }^{2}$.

${ }^{4}$ Mass of iron exported in the sediment trap. Correspond to the cumulate mass recovered in the trap (see Table 1)

5 The recovery is estimated as the percentage of the mass of iron that is recovered relative to the initial mass at $t 0$.

time $t$, the iron budget for the mesocosms is the sum of four terms:

1. The "input" term corresponds to the amount of iron added through a dust addition of $41.5 \mathrm{~g}$. The seeding is considered as the only input of iron for the entire experiments, as the mesoscosm wall isolates the water mass from further inputs and the mesocosms were covered to avoid any possible additional natural atmospheric deposition.

2./3. The $\mathrm{dFe}(<0.2 \mu \mathrm{m}-$ in $\mathrm{mg})$ and $\mathrm{pFe}(>0.2 \mu \mathrm{m}-$ in $\mathrm{mg})$ stock in the water column corresponds to the integrated amount of $\mathrm{dFe}$ and $\mathrm{pFe}$ determined in the mesocosms from $[\mathrm{dFe}]$ and $[\mathrm{pFe}]$ measurements (see Table 2 for calculations).

4. The "export" term corresponds to the amount of iron collected in the sediment trap.

It is assumed that the inventory of iron at $t 0$ is the sum of the iron added by the dust seeding and the stock of iron initially present in the mesocosms in the dissolved $(<0.2 \mu \mathrm{m})$ and particulate phase $(>0.2 \mu \mathrm{m})$. After fertilization, the recovery is the percentage of the fraction of iron present at $t 0$ that is recovered with the different measurements [dFe], [pFe] and $\mathrm{pFe}$ in the sediment trap).

The iron budget over the duration of the experiment could not be balanced with the initial $t 0$ budget: at most, ca. $60 \%$ was recovered. Several, non exclusive reasons, can explain this unbalance. First, the stock of [pFe] was calculated from discrete measurements at three depths and extrapolated to the whole water column which can lead to important errors. A layer of high dust concentration could be missed between the sampling depths and not be accounted. For instance, this could have happened in the first days of the experiment in the upper part of the mesocosm, or later in the bottom cone. This would underestimate the $\mathrm{pFe}$ stocks. Besides this interpolation artifact, other reasons related to the design of the mesocosms may explain a part of this unbalanced budget. Adsorption of dissolved iron on plastic surfaces has been demonstrated (Fisher et al., 2007). However, even if the polyethylene (PE) walls of the mesocosms would have absorb half of the dissolved iron in the mesocosms (which has been demonstrated for small PE bottles (Fisher et al., 2007)) this, still, only explains a negligible loss of iron. The dFe stock is only a small part (less than 1\%) of the iron budget (See Table 2). Mesocosm walls represent also an important surface of material where some particulate material could have stick. A visual inspection of the mesocosms at the end of the experiment did not allow establishing a significant loss by particle retention on the vertical walls of the mesocosms, but as described in Guieu et al. (2010b), a fraction of the particles could have get lost during the trap changing or have get stuck inside the bottom of the cone.

\subsection{Impact of the dust addition on dissolved iron concentration}

Even if a large debate still exists on the actual bioavaibility of different iron species in seawater (e.g. Sunda, 2001), assessing iron dissolution from dust particles through $[\mathrm{dFe}]$ $(<0.2 \mu \mathrm{m})$ measurements can be assumed to be an indicator of the amount of dust iron that may be available for the biota. Given the importance of dust deposition as a source of iron to the open ocean at a global scale, numerous studies have focused on the release of iron from dust particles in seawater (e.g. Mahowald et al., 2009). The common assumption of these works is that dust releases iron to the dissolved pool once deposited at the sea surface. However, during the DUNE-1-P experiment, after the dust addition, no dissolution of iron from dust particles could be evidenced. On the contrary, the dust addition was immediately followed by a decrease (between 0.7 to $1 \mathrm{nM}$ ) of [dFe] (Fig. 5a).

To quantify this decrease, the "loss" of dFe stock

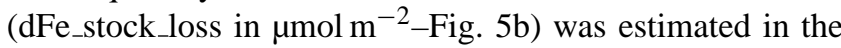
0-5 $\mathrm{m}$ and 5-10 $\mathrm{m}$ water layers as the difference between the $\mathrm{dFe}$ stock in CONTROL-meso and DUST-meso and correspond to the integrated amount of $\mathrm{dFe}$ that was removed from the dissolved pool of iron after dust seeding. This decrease would correspond to a net sink of up to $4 \mu \mathrm{mol} \mathrm{m}{ }^{-2}$ of dissolved iron in the first $48 \mathrm{~h}$ of the experiment (Fig. 5b). This sink of $\mathrm{dFe}$ could be due to enhanced biological activity since the addition of dust stimulated the biological activity in the mesocosms (Guieu et al., 2009). Chlorophyll concentration increased in all "dust" mesocosms from ca. $0.10 \mu \mathrm{g} \mathrm{L}^{-1}$ to $0.25 \mathrm{~g} \mathrm{~L}^{-1}$ (Guieu et al., 2009), and bacterial abundance increased in surface from $0.510^{6}$ to $110^{6}$ cell $\mathrm{mL}^{-1}$ (Guieu et al., 2010) within $48 \mathrm{~h}$. Although iron biological uptake was 

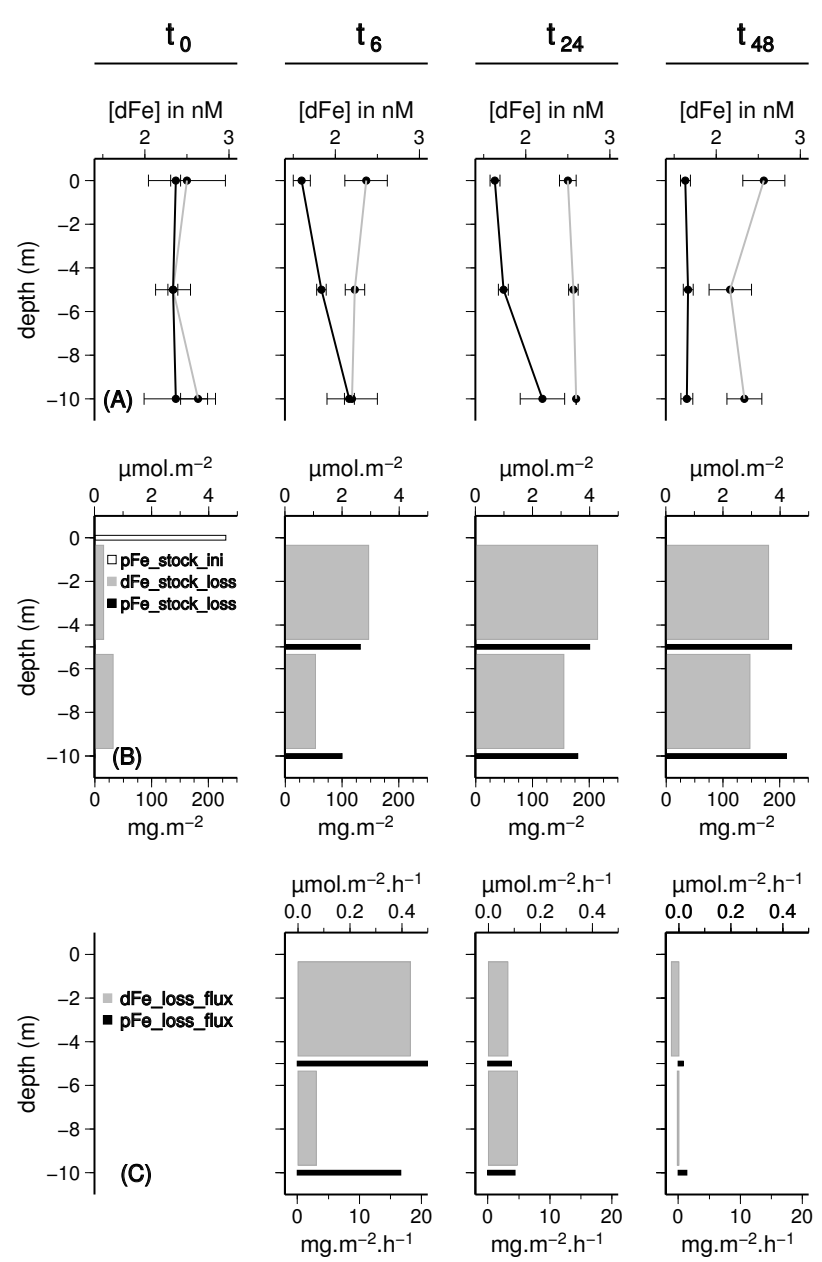

Fig. 5. Scavenging of dissolved iron on settling particles during the first $48 \mathrm{~h}$ of the DUNE-1-P experiment. All values are the average of the mesocosms triplicates. (a) $[\mathrm{dFe}]$ profiles in "CONTROLmeso" (grey line) and "DUST-meso" (black line). (b) Loss of dFe stock (dFe_stock_loss, Grey bars, top axe - difference between the $\mathrm{dFe}$ stock in CONTROL-meso and DUST-meso) and loss of pFe stock (pFe_stock_loss, black bars, bottom axe, amount of pFe introduced by the dust seeding that is lost for the $0-5 \mathrm{~m}$ layer and the $5-10 \mathrm{~m}$ layer at time $t$ ). At $t 0$, the $\mathrm{dFe}_{-}$stock_loss is due to natural variability in dFe profile in CONTROL-Meso and DUST-Meso. (c), fluxes of dFe loss (dFe_loss_flux, Grey bars, top axe) and pFe loss (pFe_loss_flux, black bars, bottom axe) are the stocks of dFe and $\mathrm{pFe}$ lost per unit of time between the different sampling times. The definition and description of the calculation of this parameters can be found in the text (Sect. 4.2).

not directly assessed during the experiment, literature values of iron content in cells can be used as estimates. In the 0 $5 \mathrm{~m}$ layer where the maximum "loss" of dFe stock occurred (Fig. 5b), the phytoplankton bloom observed during the experiment could have induced a maximum iron uptake of $375 \mathrm{nmol} \mathrm{m}^{-2} \mathrm{~d}^{-1}$ based on a C/Chla ratio of $10 \mathrm{nmol} \mathrm{g-1}$ and a Fe/C ratio of $10^{-4}$ as reported in Brand (1991) and Veldhuis et al. (2005). Concerning heterotrophic bacteria, the maxi- mum iron consumption would be $55 \mathrm{nmol} \mathrm{m}^{-2} \mathrm{~d}^{-1}$ based on the $\mathrm{Fe} / \mathrm{C}$ ratio of $44 \times 10^{-6}$ reported by Tortell et al. (1996) and a carbon quota of $2 \mathrm{fmol} \mathrm{cell}^{-1}$ higher than reported by Fukuda et al. (1998). A reasonable overestimation of the biological consumption of iron could then be roughly assumed to be in a range of $500-1000 \mathrm{nmol} \mathrm{m}^{-2} \mathrm{~d}^{-1}$. In the first hours of the experiment the dissolved iron decrease rate in DUSTmeso was up to $400 \mathrm{nmol} \mathrm{m}^{-2} \mathrm{~h}^{-1}\left(9600 \mathrm{nmol} \mathrm{m}^{-2} \mathrm{~d}^{-1}\right)$, one order of magnitude higher than this overestimated biological consumption of iron, suggesting that enhanced biological activity cannot explain by itself the observed decrease in dissolved iron.

A more plausible explanation for the observed sink of iron is that dust particles scavenged dissolved iron as they settled in the water column. As pointed out in a recent review (Baker and Croot, 2010), investigation of direct scavenging on dust particles are very limited. However, scavenging of dissolved iron on settling particles represents the highest potential sink of dissolved iron for the ocean (Johnson et al., 1997). Zhuang and Duce (1993), based on radiolabeled ${ }^{59} \mathrm{Fe}$ studies, have reported values of iron adsorption of $27 \mathrm{nmol} \mathrm{mg}^{-1}$ on dust particles. Based on the study of pure hematite phases and radiolabeled ${ }^{59} \mathrm{Fe}$, Honeyman and Santschi (1991), reported the importance of the colloidal phase formation on the scavenging of trace metals on particulate iron. The design of the DUNE experiment allowed to study this process by following $[\mathrm{dFe}]$ variations during the settling of the dust particles in the first $10 \mathrm{~m}$ of the water column.

In order to demonstrate the scavenging of $\mathrm{dFe}$ on settling dust particles in the first $48 \mathrm{~h}$ of the experiment, the following terms were estimated based on average values for CONTROL-meso and DUST-meso: (1) The "loss" of dFe stock (dFe_stock_loss in $\mu \mathrm{mol} \mathrm{m}{ }^{-2}$ ) was estimated as the difference between the dFe stock in CONTROL-meso and DUST-meso as mentioned before. (2) The "loss" of pFe stock ( $\mathrm{pFe}$ _stock_loss in $\mathrm{mg} \mathrm{m}^{-2}$ ) was defined as the amount of pFe introduced by the dust seeding that is lost for the 0 $5 \mathrm{~m}$ layer and the 5-10 m layer at time $t$, based on the basic assumption that dust particles have only a vertical motion to the bottom in the mesocosms. Thus pFe_stock_loss was calculated at 5 and $10 \mathrm{~m}$ by subtracting the stock of pFe determined by $[\mathrm{pFe}]$ measurements between $0-5 \mathrm{~m}$ and $0-10 \mathrm{~m}$ (assuming that all pFe measured comes from the added particles, supported by results in Sect. 3.2.) to the initial stock of $\mathrm{pFe}$ introduced by dust $\left(\mathrm{pFe} \_\right.$stock_ini $=231 \mathrm{mg} \mathrm{m}^{-2}$ ). pFe_stock_loss is, theoretically, the stock of pFe introduced by the seeding that has been in contact with the stock of $\mathrm{dFe}$ between $0-5 \mathrm{~m}$ and 5-10 $\mathrm{m}$ and that has crossed the "conceptual" 5 and $10 \mathrm{~m}$ horizons while settling. dFe_stock_loss and pFe_stock_loss are presented on Fig. 5b. (3) pFe_loss_flux (in $\mathrm{mg} \mathrm{m}^{-2} \mathrm{~h}^{-1}$ ) and dFe_loss_flux (in $\mu \mathrm{mol} \mathrm{m} \mathrm{m}^{-2} \mathrm{~h}^{-1}$ ) correspond to the stock of $\mathrm{dFe}$ and $\mathrm{pFe}$ lost per unit of time between the different sampling times (Fig. 5c). It can be noted that the pFe_loss_flux at 5 and $10 \mathrm{~m}$ should be proportional to the average settling velocity of dust particles between two 
sampling times. As expected, pFe_loss_flux decreased between 6 and $48 \mathrm{~h}$. Indeed, the largest particles would settle faster in the first hours and then smaller particles would settle with lower velocities.

As illustrated on Fig. 6a, the decrease of dFe stock is correlated to the stock of $\mathrm{pFe}$ that settles through the water column after the dust addition. Moreover, the flux of dFe loss throughout the water column is even better correlated to the pFe_loss_flux (Fig. 6b). This is a robust indication of the scavenging of dissolved iron onto the particulate matter (particularly dust) that settles to the bottom of the mesocosm after the dust addition. Those results demonstrate that the dust addition in this experiment was a sink rather than a source of bioavailable iron.

The slope of the linear models on Fig. 6 provides an estimation of the $\mathrm{dFe}$ scavenging rate on Saharan dust particles settling in the water column. The estimated values of scavenging are $17 \pm 7$ and $15 \pm 6 \mathrm{nmol} \mathrm{mg}^{-1}$ for particulate iron. By converting the particulate iron into dust concentration, dFe scavenging would be $0.39 \pm 0.12$ and $0.35 \pm 0.12 \mathrm{nmol} \mathrm{mg}^{-1}$ of dust. These values are two orders of magnitude lower than the values estimated by Zhuang and Duce (1993) of $27 \mathrm{nmol} \mathrm{mg}^{-1}$. The reasons for these differences will be discussed in Sect. 4.5.

\subsection{Impact of dust seeding on the solubilisation capacity of seawater}

The goal of the batch dissolution experiments using filtered seawater collected in the mesocosms at different times after the seeding was to evaluate the impact of dust fertilization on the solubilisation capacity of the seawater. Indeed, the ultimate factor controlling dust solubility in seawater is the capacity of seawater to keep iron in solution through the presence of organic ligands (Liu and Millero, 2002; Baker and Croot, 2010). In a recent study, Wagener et al. (2008) showed that iron dissolution from dust particles in seawater changes over an annual cycle in the Mediterranean Sea and is controlled by the concentration of dissolved organic carbon with higher dissolution in presence of fresh organic matter in the post bloom period.

Before the dust addition, the solubility of iron dust particles in filtered seawater was very low or even null (Fig. 4) showing that solubility equilibrium between $\mathrm{pFe}$ and $\mathrm{dFe}$ was reached.

After dust addition, at $t=48 \mathrm{~h}$ and $t=120 \mathrm{~h}$, the dissolution of iron from dust was detectable in the DUST-meso batch experiments (with $\Delta[\mathrm{dFe}]_{72} \mathrm{~h}$ of ca. $0.6 \mathrm{nM}$ ) whereas no detectable dissolution in CONTROL-meso was observed. Two mechanisms could support this increase in dust iron solubility in DUST-meso after $48 \mathrm{~h}$ :

1. Specific iron binding ligands were produced by phytoplankton (Boye and Van den Berg, 2000) or heterotrophic bacteria (Gledhill et al., 2004) and
2. The scavenging of colloidal iron on dust particles or the re-precipitation of soluble iron favored by the important amount of solid particles was induced by the dust addition in the mesocosms. After addition of new iron by dust particles in the batch experiments, stabilization of new iron in the form of soluble or colloidal iron could then have taken place and would explain the relative increase of $[\mathrm{dFe}]$ in DUST-Meso.

At the end of the experiment $(t=168 \mathrm{~h})$, there was a clear increase of the iron solubilisation capacity of DUST-meso seawater. This may be related to the formation of organic binding sites induced by increased biological activity. Former studies have demonstrated an increase of iron binding ligands a few days after an increase of biological productivity (Croot et al., 2001). One possible mechanism responsible for the observed increase in the dust dissolution capacity is the production of siderophores by heterotrophic bacteria. The $[\mathrm{dFe}]$ decrease and the appearance of a new source of non available iron that followed the dust seeding could have enhanced the bacterial production of siderophores. This hypothesis is supported by the observation that the diversity of the bacterial community attached to particles revealed some distinct features in the mesocosms amended with dust at the end of the experiment (Laghdass et al., 2010). The increase of zooplankton biovolume in DUST-meso (Stemman, personal communication, 2009 and Guieu et al., 2009) could also lead to enhanced organic binding sites through the release of porphyrine-like ligands by increased grazing (Vong et al., 2009).

\subsection{Implication for the understanding of iron dust dissolution in seawater}

Two distinct protocols have been used in the last years to assess the solubility of aerosols in seawater: flow through protocols (See for ex. Buck et al., 2006) and batch experiments (see for ex. Bonnet and Guieu, 2004). Although these protocols bring different information on the dissolution process (Baker and Croot, 2010) both conclude that a certain amount of iron dissolves from the dust particles. In this study, the addition of dust particles in the mesocosm did not result in a net release of dissolved iron to seawater but in a sink. However, batch dissolution experiments performed in parallel to the mesocosm experiment, did not demonstrate iron scavenging but dissolution when using the water collected in the DUSTMeso where increase in biological activity was evidenced.

In mesocosm studies, due to the settling of the particles through the water column, the concentration of dust particles in the mesocosm is time and depth dependent whereas batch experiments are perfectly homogeneous reactors where a constant concentration can be defined over time. A concentration of $5 \mathrm{mg} \mathrm{L}^{-1}$ was used for batch experiments, which would correspond to a realistic mixing of the added particles in the first two meters of the water column in the mesocosms. 

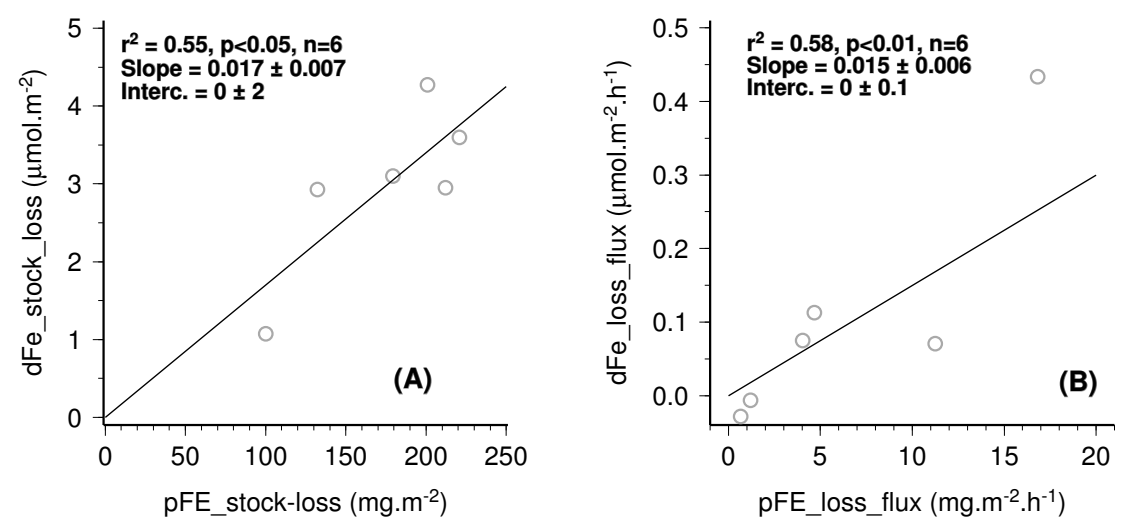

Fig. 6. Correlation between $\mathrm{dFe}$ and $\mathrm{pFe}$ stock loss (a) and fluxes of $\mathrm{dFe}$ and $\mathrm{pFe}$ loss (b). The definition and description of the calculation of this parameters can be found in the text (Sect. 4.2).

The major differences obtained between the batch experiments and the mesocosm studies are certainly more related to the nature of the mixing of the particles in the water than to a simple difference in concentration. Moreover, the surface to volume ratio $(S / V)$ was $251 \mathrm{~m}^{-1}$ for the bottles used in the batch experiments whereas for mesocosms it was of $1.82 \mathrm{~m}^{-1}$. This two order of magnitude difference may have enhanced the adsorption on the walls of the reactors compared to the mesocosms study. This would hence have induced a lower dissolution in batch experiments. This also confirms that the observed differences were due to an actual difference in the dynamic process of the particle settling rather than to an experimental artifact. These results underline the crucial importance of the protocols used for dust iron dissolution measurements.

Flow through protocols could be seen as appropriate to mimic the dynamical process of particle settling in the water column. However, the contact time between particles and seawater is too short (a few seconds) for the scavenging processes to take place. Even if this protocol has the clear advantage to be easy to handle and to bring information on the control of dust iron solubility by aerosols characteristics (Buck et al., 2006), it has clear limitations in terms of marine biogeochemical perspectives, as the complex equilibrium between adsorption and dissolution that occurs during particle settling in the surface ocean is not taken into account.

Batch experiments could be more appropriate to investigate the processes that occur when atmospheric particles are mixed into the oceanic mixed layer. However, this type of experiments may be subject to another artifact because the contact between particles and seawater is constant, that is, the dynamical nature of the dust deposition of particles is not taken into account by this protocol. This could lead to important adsorption on dust particles as demonstrated by Zhuang and Duce (1993) that would not occur with shorter contact times. Slower dissolution processes, that would not have time to occur in a dynamical process where particles are settling, could also lead to wrong dissolution evaluation by this protocol.
Although mesocosms studies are not easy to handle, they do better represent the natural conditions. In particular, the parametrization obtained integrates the biological compartment and the biogeochemical characteristics of the large body of water enclosed inside the bags do evolve after the introduction of the particles. This allows to account for dynamical equilibrium that occurs in natural conditions: (1) The fertilization induced by the injection of atmospheric nutrient can lead to production of fresh organic matter prone to complex iron and (2) the settling of particles in the mesocosm allow to represent realistically the scavenging of dissolved iron from the water column. For example, we can hypothesize that the presence of dissolved and particulate organic matter allowed the formation of mineral-organic aggregates which have affected the scavenging of dissolved iron and accelerating its export. This hypothesis agrees with recent observations suggesting that organic-Saharan mineral aggregation results, through ballast effect, in a strong POC export in the water column of the NW Mediterranean Sea (Ternon et al., 2010).

\subsection{Implications for the biogeochemical functioning of high dust deposition areas}

The DUNE-1-P experiment mimicked a strong but realistic dust deposition event $\left(10 \mathrm{~g} \mathrm{~m}^{-2}\right)$. Indeed, several strong dust events recently recorded in NW Mediterranean did bring within few hours dust fluxes higher than $10 \mathrm{~g} \mathrm{~m}^{-2}$ (Guieu et al., 2010a; Bonnet and Guieu, 2006; Ternon et al., 2010). The classical image of dust deposition releasing nutrients (such as $\mathrm{Fe}$ ) in the surface ocean, fueling biological productivity and thus increasing the biological carbon pump efficiency (e.g. Cassar et al., 2007), is partly revisited in this study. Dust deposition is more complex than just a source of bioavailable iron to the surface ocean: a large dust deposition event can accelerate the export of iron from the water column through scavenging and can be described with a counter-intuitive "dust cleaning effect". 
It has been argued that, because of the enhanced solubility of atmospheric dust particulate iron that has been transported over long distances (e.g. Baker and Jickels, 2006; Chi et al., 2009), in areas far from from dust sources, the flux of atmospheric dissolved iron could be high in comparison to the total deposition flux (Fan et al., 2006). This study present evidences of the opposite effect: in areas receiving large dust deposition, dFe scavenging onto the atmospheric particles may be promoted and thus, large fluxes of total iron may lead to relatively small fluxes of dissolved iron. Moreover, in areas with high seawater dissolved iron and high dust deposition (i.e. oligotrophic areas $\mathrm{P}$ - or N-limited such as the Mediterranean Sea or the Tropical Atlantic), a strong dust event could even induce a sink for dissolved iron. This implies that atmospheric dissolved iron inputs to the surface ocean are not linearly linked to dust deposition: low dust areas are relatively favored in comparison to high dust deposition areas.

This study illustrates another potentially important biogeochemical response to dust deposition: the occurrence of successive dust deposition events could have a different effect than one isolated event. In P-limited areas, a first dust deposition event may induce an increase of biological activity triggered by the input of limiting nutrients (e.g. phosphorus (Pulido-Villena et al., 2010)). This could, in turn, induce an increase in the iron binding capacity of seawater. A second deposition event in a short time period (few days) could, thus, induce a much larger release of bioavailable iron.

This work demonstrates that the quantification of the inputs of dissolved iron from dust in the surface ocean cannot be restricted to a simple determination of atmospheric fluxes. Complex atmospheric and oceanic processes at different time scales have to be considered in order to get a realistic picture of the role of dust deposition on marine iron cycle.

Acknowledgements. This work was funded by the ANR-DUNE under the contract "ANR-07-BLAN-0126-01". We would like to thank the "Réserve naturelle de Scandola, Parc naturel régional de Corse", in particular J. M. Dominici and collaborators, for professionalism and cooperation in the implementation of the field work in the bay of Elbo. F. Louis, J. M. Grisoni, D. Luquet, M. Deschatres, C. Ridame, E. Pulido-Villena, S. Blain, C. Brunet, L. Gilleta and C. Rouvières are greatly acknowledged for their involvement during the DUNE-1 experiment. P. Rendinella is thanked for her help in sediment trap treatment and ICP-AES measurements. S. Blain, F. Dulac and K. Desboeuf are acknowledged for their comments and suggestions on the manuscript.

Edited by: K. Küsel

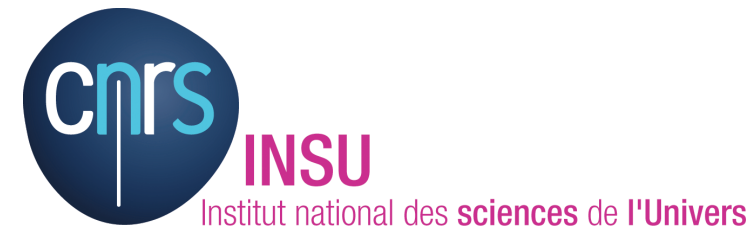

The publication of this article is financed by CNRS-INSU.

Supplementary material related to this
article is available online at:
http://www.biogeosciences.net/7/3769/2010/
bg-7-3769-2010-supplement.zip.

\section{References}

Andreae, M. O.: Raising dust in the greenhouse, Nature, 380, 389 390, 1996.

Aumont, O., Bopp, L., and Schulz, M.: What does temporal variability in aeolian dust deposition contribute to sea-surface iron and chlorophyll distributions?, Geophys. Res. Lett., 35, L07607, doi:10.1029/2007GL031131, 2008.

Baker, A. R. and Croot, P. L.: Atmospheric and marine controls on aerosol iron solubility in seawater, Mar. Chem., 120, 4-13, doi:10.1016/j.marchem.2008.09.003, 2010.

Baker, A. R. and Jickells, T. D.: Mineral particle size as a control on aerosol iron solubility, Geophys. Res. Lett., 33, L17608, doi:10.1029/2006GL026557, 2006.

Bonnet, S. and Guieu, C.: Dissolution of atmospheric iron in seawater, Geophys. Res. Lett., 31(3), L03303, doi:10.1029/2003GL018423, 2004.

Bonnet, S. and Guieu, C.: Atmospheric forcing on the annual iron cycle in the western Mediterranean Sea: A 1-year survey, J. Geophys. Res., 111(C9), C09010, doi:10.1029/2005JC003213, 2006.

Bopp, L., Kohfeld, K. E., Le Quere, C., and Aumont, O.: Dust impact on marine biota and atmospheric $\mathrm{CO} 2$ during glacial periods, Paleoceanography, 18(2), 1046, doi:10.1029/2002PA000810, 2003.

Boyd, P. W., Jickells, T., Law, C. S., Blain, S., Boyle, E. A., Buesseler, K. O., Coale, K. H., Cullen, J. J., de Baar, H., Follows, M., Harvey, M., Lancelot, C., Levasseur, M., Owens, N., Pollard, R., Rivkin, R. B., Sarmiento, J., Schoemann, V., Smetacek, V., Takeda, S., Tsuda, A., Turner, S., and Watson, A. J.: Mesoscale Iron Enrichment Experiments 19932005: Synthesis and Future Directions, Science, 315, 612-617, doi:10.1126/science.1131669, 2007.

Boye, M. and van den Berg, C. M. G.: Iron availability and the release of iron complexing ligands by Emiliania huxleyi, Mar. Chem., 70, 277-287, 2000.

Brand, L. E.: Minimum iron requirements of marine phytoplankton and the implication of biogeochemical contol of new production, Limnol. Oceanogr., 36, 1756-1771, 1991.

Buck, C. S., Landing, W. M., Resing, J. A., and Lebon, G. T.: Aerosol iron and aluminium solubility in the northwest Pacific Ocean: Results from the 2002 IOC cruise, Geochem. Geophys. Geosyst., 7(4), Q04M07, doi:10.1029/2005GC000977, 2006. 
Bruland, K. W., Franks, R. P., Knauer, G. A., and Martin, J. H.: Sampling and analytical methods for the determination of copper, cadnium, zinc and nickel at the nanogram per liter level in seawater, Anal. Chim. Acta, 105, 233-245, 1979.

Cassar, N., Bender, M. L., Barnett, B. A., Fan, S., Moxim, W. J., Levy, I., and Tilbrook, B.: The Southern Ocean Biological Response to Aeolian Iron Deposition, Science, 317, 1067-1070, doi:10.1126/science.1144602, 2007.

Claquin, T.; Schulz, M., and Balkanski, Y.: Modeling the mineralogy of atmospheric dust sources, J. Geophys. Res., 104(D18), 22243-22256, doi:10.1029/1999JD900416, 1999.

Croot, P. L., Bowie, A. R., Frew, R. D., Maldonado, M. T., Hall, J. A., Safi, K. A., La Roche, J., Boyd, P. W., and Law, C. S.: Retention of dissolved iron and $\mathrm{Fe}-\mathrm{II}$ in an iron induced Southern Ocean phytoplankton bloom, Geophys. Res. Lett., 28(18), 34253428, doi:10.1029/2001GL013023, 2001.

Desboeufs, K. V., Losno, R., and Colin, J. L.: Relationship between droplet $\mathrm{pH}$ and aerosol dissolution kinetics: Effect of incorporated aerosol particles on droplet $\mathrm{pH}$ during cloud processing, J. Atmos. Chem., 46, 159-172, 2003.

Duce, R. A., LaRoche, J., Altieri, K., Arrigo, K. R., Baker, A. R., Capone, D. G., Cornell, S., Dentener, F., Galloway, J., Ganeshram, R. S., Geider, R. J., Jickells, T., Kuypers, M. M., Langlois, R., Liss, P. S., Liu, S. M., Middelburg, J. J., Moore, C. M., Nickovic, S., Oschlies, A., Pedersen, T., Prospero, J., Schlitzer, R., Seitzinger, S., Sorensen, L. L., Uematsu, M., Ulloa, O., Voss, M., Ward, B., and Zamora, L.: Impacts of Atmospheric Anthropogenic Nitrogen on the Open Ocean, Science, 320, 893, 893-897, doi:10.1126/science.1150369, 2009.

Fukuda, R., Ogawa, H., Nagata, T., and Koike, I.: Direct determination of carbon and nitrogen contents of natural bacterial assemblages in marine environments, Appl. Environ. Microbiol., 64, 3352-3358, 1998.

Gledhill, M., McCormack, P., Ussher, S., Achterberg, E. P., Mantoura, R. F. C., and Worsfold, P. J.: Production of siderophore type chelates by mixed bacterioplankton populations in nutrient enriched seawater incubations, Mar. Chem., 88, 75-85, 2004.

Guieu, C.: DUNE - a Dust experiment in a low Nutrient, low Chlorophyll Ecosystem - Quantifying the role of atmospheric input on marine ecosystem using large clean mesocosms, SOLAS Newsletter, 9, 36-37, 2009.

Guieu, C., Loye-Pilot, M. D., Ridame, C., and Thomas, C.: Chemical characterization of the Saharan dust end-member: Some biogeochemical implications for the western Mediterranean Sea, J. Geophys. Res., 107(D15), 4258, doi:10.1029/2001JD000582, $2002 a$.

Guieu, C., Bozec, Y., Blain, S., Ridame, C., Sarthou, G., and Leblond, N.: Impact of high Saharan dust inputs on dissolved iron concentrations in the Mediterranean Sea, Geophys. Res. Lett., 29(19), 1911, doi:10.1029/2001GL014454, 2002b.

Guieu, C., Roy-Barman, M., Leblond, N., Jeandel, C., Souhaut, M., Le Cann, B., Dufour, A., and Bournot, C.: Vertical particle flux in the northeast Atlantic Ocean (POMME experiment), J. Geophys. Res., 110(C7), C07S18, doi:10.1029/2004JC002672, 2005.

Guieu, C., Loÿe-Pilot, M. D., Benyahya, L., and Dufour, A.: Spatial variability of atmospheric fluxes of metals $(\mathrm{Al}, \mathrm{Fe}$, $\mathrm{Cd}, \mathrm{Zn}$ and $\mathrm{Pb}$ ) and phosphorus over the whole Mediterranean from a one-year monitoring, Mar. Chem., 120, 164-178, doi:10.1016/j.marchem.2009.02.004, 2010a.
Guieu, C., Dulac, F., Desboeufs, K., Wagener, T., Pulido-Villena, E., Grisoni, J.-M., Louis, F., Ridame, C., Blain, S., Brunet, C., Bon Nguyen, E., Tran, S., Labiadh, M., and Dominici, J.M.: Large clean mesocosms and simulated dust deposition: a new methodology to investigate responses of marine oligotrophic ecosystems to atmospheric inputs, Biogeosciences, 7, 27652784, doi:10.5194/bg-7-2765-2010, 2010b.

Guieu, C., Ridame, C., Pulido-Villena, E., Blain, S., Wagener, T., Dulac, F., Desboeufs, K., Pondaven, P., Leblond, N., Stemman, L., Obernesterer, I., and Dominici, J. M.: Dust inputs and marine carbon cycle: new insights from mesocosms study, in preparation, 2010.

Fan, S. M., Moxim, W. J., and Levy, H.: Aeolian input of bioavailable iron to the ocean, Geophys. Res. Lett., 33, L07602, doi:10.1029/2005GL024852, 2006.

Fischer, A., Kroon, J., Verburg, T., Teunissen, T., and Wolterbeek, T. H.: On the relevance of iron adsorption to container materials in small-volume experiments on iron marine chemistry: ${ }^{55} \mathrm{Fe}$ aided assessment of capacity, affinity and kinetics, Mar. Chem., 107, 533-546, 2007.

Honeyman, B. D. and Santschi, P. H.: Coupling adsorption and particle aggregation: laboratory studies of "colloidal pumping" using 59Fe-labeled hematite, Environ. Sci. Technol. 25, 17391747, 1991.

Jickells, T. D., An, Z. S., Andersen, K. K., Baker, A. R., Bergametti, G., Brooks, N., Cao, J. J., Boyd, P. W., Duce, R. A., Hunter, K. A., Kawahata, H., Kubilay, N., laRoche, J., Liss, P. S., Mahowald, N., Prospero, J. M., Ridgwell, A. J., Tegen, I., and Torres, R.: Global iron connections between desert dust, ocean biogeochemistry, and climate, Science, 308, 67-71, doi:10.1126/science.1105959, 2005.

Johnson, K., Boyle, E., Bruland, K., Coale, K., Measures, C., Moffet, J., Aguilar-islas, A., Barbeau, K., Bergquist, B., Bowie, A., and Buck, K.: Developing Standards for dissolved Iron in Seawater, EOS Transactions, 88, 131-132, 2007.

Laghdass, M., Blain, S., Besseling, M., Catala, P., Guieu, C., and Obernosterer, I.: Impact of Saharan dust on the microbial community during a large clean mesocosm experiment in the NW Mediterranean Sea, Aquat. Microb. Ecol., in press, doi:10.3354/ame01466, 2010.

Liu X. and Millero, F. J.: The solubility of iron in seawater, Mar. Chem., 77, 43-54, 2002.

Mahowald, N., Jickells, T. D., Baker, A. R., Artaxo, P., BenitezNelson, C. R., Bergametti, G., Bond, T. C., Chen, Y., Cohen, D. D., Herut, B., Kubilay, N., Losno, R., Luo, C., Maenhaut, W., McGee, K. A., Okin, G. S., Siefert, R. L., and Tsukuda, S.: Global distribution of atmospheric phosphorus sources, concentrations and deposition rates, and anthropogenic impacts, Global Biogeochem. Cy., 22, GB4026, doi:10.1029/2008GB003240, 2008.

Mahowald, N., Engelstaedter, S., Luo, C., Sealy, A., Artaxo, P., Benitez-Nelson, C., Bonnet, S., Chen, Y., Chuang, P. Y., Cohen, D. D., Dulac, F., Herut, B., Johansen, A. M., Kubilay, N., Losno, R., Maenhaut, W., Paytan, A., Prospero, J. M., Shank, L. M., Siefert, R. L.: Atmospheric Iron deposition: Global distribution, variability and human perturbations, Annual Reviews of Marine Sciences, 1, 245-278, doi:10.1146/annurev/marine.010908.163727, 2009. 
Martin, J.: Glacial-Interglacial CO2 Change: The Iron Hypothesis, Paleoceanography, 5, 1-13, 1990.

Mills, M. M., Ridame, C., Davey, M., La Roche, J., and Geider, R. J.: Iron and phosphorus co-limit nitrogen fixation in the eastern tropical North Atlantic, Nature, 429, 292-294, 2004.

NASA EO: http://earthobservatory.nasa.gov/, last access: 18 November 2010, 2010.

Pulido-Villena, E., Rérolle, V., and Guieu, C.: Transient fertilizing effect of dust in P-deficient LNLC surface ocean, Geophys. Res. Lett., 37, L01603, doi:10.1029/2009GL041415, 2010.

Sarthou, G. and Jeandel, C.: Seasonal variations of iron concentrations in the Ligurian Sea and iron budget in the Western Mediterranean Sea, Mar. Chem., 74, 115-129, 2001.

Sedwick, P. N., Church, T. M., Bowie, A. R., Marsay, C. M., Ussher, S. J., Achilles, K. M., Lethaby, P. J., Johnson, R. J., Sarin, M. M., and McGillicuddy, D. J.: Iron in the Sargasso Sea (Bermuda Atlantic Time-series Study region) during summer: Eolian imprint, spatiotemporal variability, and ecological implications, Global Biogeochem. Cy., 19(4), GB4006, doi:10.1029/2004GB002445, 2005.

Shi, Z., Krom, M. D., Bonneville, S., Baker, A. R., Jickells, T. D., and Benning, L. G.: Formation of Iron Nanoparticles and Increase in Iron Reactivity in Mineral Dust during Simulated Cloud Processing, Environ. Sci. Technol., 43, 6592-6596, doi:10.1021/es901294g, 2009.

Spokes, L. and Jickells, T.: Factors controlling the solubility of aerosol trace metals by cloud in the atmosphere and on mixing into seawater, Aquatic Geochem., 1, 355-374, 1995.

Ternon, E., Guieu, C., Loÿe-Pilot, M.-D., Leblond, N., Bosc, E., Gasser, B., Miquel, J.-C., and Martín, J.: The impact of Saharan dust on the particulate export in the water column of the North Western Mediterranean Sea, Biogeosciences, 7, 809-826, doi:10.5194/bg-7-809-2010, 2010.
Tortell, D., Madonado, M. T., and Price, N. M.: The role of heterotrophic Bacteria in iron-limited ocean ecosystems, Nature, 383, 330-332, 1996.

Veldhuis, M. J., Timmermans, K. R., Croot, P., van der Wagt B.: Picophytoplankton; a comparative study of their biochemical composition and photosynthetic properties, J. Sea Res., 53, 7-24, doi:10.1016/j.seares.2004.01.006, 2005.

Volpe, G., Banzon, V. F., Evans, R. H., Santoleri, R., Mariano, A. J., and Sciarra, R.: Satellite observations of the impact of dust in a low-nutrient, low-chlorophyll region: Fertilization or artifact?, Global Biogeochem. Cy., 23, GB3007, doi:10.1029/2008GB003216, 2009.

Vong, L., Laes, A., and Blain, S.: Determination of iron-porphyrinlike complexes at nanomolar levels in seawater, Anal. Chim. Acta, 588, 237-244, doi:10.1016/j.aca.2007.02.007, 2007.

Wagener, T., Pulido-Villena, E., and Guieu, C.: Dust iron dissolution in seawater: Results from a one-year time-series in the Mediterranean Sea, Geophys. Res. Lett., 35, L16601, doi:10.1029/2008GL034581, 2008.

Watson, A., Bakker, D., Ridgwell, A., Boyd, P., and Law, C.: Effect of iron suplly on Southern Ocean $\mathrm{CO}_{2}$ uptake and implications for glacial atmospheric $\mathrm{CO}_{2}$, Nature, 407, 730-733, 2000.

Wedepohl, K.: The composition of the continental crust, Geochim. Cosmochim. Acta, 59, 1217-1232, 1995.

Zhuang, G. and Duce, R.: The adsorption of dissolved iron on marine aerosol particles in surface waters of the open ocean, Deep Sea Res., 40, 1413-1429, 1993. 